\title{
Empowerment State of Transgender People in Bangladesh: A Study on Savar National Memorial Based Area in Dhaka City
}

\author{
Sakina Akter Sema ${ }^{1,2}$, and Md. Touhidul Islam ${ }^{3,4}$ \\ ${ }^{1}$ Dept. of English, Pundra University of Science and Technology, Bogura, Bangladesh; ${ }^{2}$ M.Phil Research Fellow, Dept. of \\ English, Jahangirnagar University, Savar, Dhaka, Bangladesh; and ${ }^{3}$ Dept. of Business Administration, Gono Bishwabidyalay, \\ Savar, Dhaka, Bangladesh; and ${ }^{4}$ M.Phil Research Fellow, Dept. of Finance and Banking, Jahangirnagar University, Savar, \\ Dhaka, Bangladesh \\ *Correspondence: $\underline{\text { sakinaseema40@gmail.com }}$
}

\begin{abstract}
Still today at $21^{\text {st }}$ century Transgender is a mysterious issue to the common people. General people are curious to know about their lifestyle, how they fight for their livelihoods by struggling with various obstacles against them. In Bangladesh, the scenario is not different from the other neighboring countries. But presently some NGOs, Organizations and groups have come out to help them with the government. They are trying to facilitate them by involving the transgender people in various social and economic activities by giving them some training and proper counseling. Through this sort of activity they are being empowered. This research paper has quantified the extent to which the transgender people are being empowered and enjoying their empowerment as a recognized citizen of Bangladesh respects social, political-legal and economic aspects. The study has applied a descriptive research design with a quantitative approach to determine the extent of each factor in the analysis. Data were collected through a close-end structured liker scale questionnaire. The sample size was 28 respondents from the 60-80 population who live in the Savar National Memorial based area in Dhaka city. Data was analyzed by using descriptive analysis (means and standard deviation) and multiple linear regression analysis. The study found that, Social Empowerment of Transgender People (SocEm) and Economic Empowerment of Transgender People (EcoEm) have a significant positive relationship with empowerment state of transgender people while Political/Legal Empowerment of Transgender People (PoLeEm) does not have any significant positive relationship with the empowerment state of transgender people in Bangladesh respect to Savar National Memorial based area in Dhaka city. The coefficient of determination (Adjusted $R^{2}=0.901$ ) showed that $90.10 \%$ of the success recorded in the empowerment state of the transgender people in Bangladesh accounted for Economic Empowerment of Transgender People (EcoEm), Political/Legal Empowerment of Transgender People (PoLeEm), Social Empowerment of Transgender People (SocEm) respect to selected transgender people those who live in Savar National Memorial based area in Dhaka City.
\end{abstract}

Keywords: Transgender, Hijra, Empowerment, MDGs, Savar National Memorial, and SDGs.

\section{INTRODUCTION:}

Generally, people are habituated to identify the gender into two types male or female but the third option those who have no specific identity that they are male or female popularly known as Hijra people in Bangladesh are normally ignored (Sema, 2019). But they are also human being and they are the part of society and their existence can't be ignored. The 
individuals who are categorized as neither man nor woman and exist with a separate physical structure are called transgender in English (Delliswararao and Hangsing, 2018). They are not transgender by birth rather their minds, thoughts, choice, and priority have been developed and transformed with their growing up. Belonging from a separate gender is not a curse rather it's a sexual identity (NHRC, 2015).

The Agenda for Sustainable Development within 2030, adopted by all the Member Countries of UN in 2015, provides a shared blueprint for peace and prosperity for people in the globe, at present and into the future. At its heart, there are the seventeen Sustainable Development Goals (SDGs), which are an immediate call for actions by all member countries developed and developing - in a global partnership. They ensure that to end the poverty and other deprivations must go hand-in-hand with different plans that improve health and education, reduce inequalities, and spur economic growth and development all while tackling climate change and working to save our oceans and forests (UN, 2016). Bangladesh already has met several targets of the Millennium Development Goals (MDGs) and now on the road to achieve the targets of Sustainable Development Goals (SDGs). To achieve the targets of SDGs if the third gender or Transgender (Hijra People) of this country gets privileges then the achievement will be tremendous. To do this the government and respective authority should focus on some specific issues or targets like- (1) No poverty, (2) Zero hunger, (4) Quality education, (5) Gender Equality and (8) Decent work and Economic growth. So Gender Equality is an important agenda of United Nations all over the world to ensure proper development of all human societies. Bangladesh is not behind to grasp the importance of such targets and doing as best as it can. That is why the gender discrimination rate is being reduced now a day. All people regardless of their gender identity getting numerous facilities from the society, government or respective authorities.

In Bangladesh, as third gender hijras have created a new identity of them. Their life leading style is totally different from others. There are dissimilarities between their livelihood and the mainstream context of society. They have limitations regarding culture, behavior and religious celebrations though they have gotten their recognition as the third gender on 11 November 2013. A landmark decision was made by the Bangladesh Government by acknowledging the Hijra's as the third gender and this recognition ensures their rights, enabling them to identify their gender as 'Hijra' in all government documents, including passports and others. This landmark decision will help them to identify their gender as 'Hijra' when personal or individual information needs to be furnished. The respective cabinet secretary noted the community was "being denied their rights in various sectors, including education, health and housing because of being a marginal group (Ahmed, 2017). This study seeks to answer the question that to what extent the transgender people are being empowered and enjoying their empowerment as a recognized citizen of Bangladesh respect to social, political-legal and economic aspects? A survey was done on selected 28 transgender people as respondents for the study of those who live in Savar National Memorial based area in Dhaka City. The results indicate that the Social and Economic empowerment of transgender people has the statistical significant relationship with their overall state of empowerment.

\section{Background of the Study}

Transgender is a case of mystery not only in this country but all over the world. The transgender people in Bangladesh are commonly known as 'Hijra'. From the very beginning of the history they are leading a different life, differentiated from the common people. They might have left their family and went with the other transgender people leaving behind their all possessions, rights, expectations to have a normal life. Previously they lead very miserable life to be described. This research was started on basis of their pathetic situation. The researchers were on the field to find the present state of their condition regarding their livelihood and others. But surprising fact is that their miserable situation is being reducing day by day. Apart from that there is something related to their life should be unboxed. In order to explore that issue this research has been formed. This study is very important in the perspective of our country as the contemporary picture of transgender people in other countries is not like ours. 


\section{Research Questions:}

It is said that, in Bangladesh the gender discrimination rate is decreasing very rapidly. All are being empowered regardless their gender identity. This study was an attempt to find the truth of the statement. After reviewing the existing literature the researchers have found many questions regarding transgender issues as third gender in Bangladesh. But the scope is limited to find answers of all the questions in a single study. That is why the researchers have identified only one research question associated with the study. The research question is;

$>$ To what extent the transgender people are being empowered and enjoying their empowerment as a recognized citizen of Bangladesh respect to social, political-legal and economic aspect's?

\section{Objective of the Study:}

\section{General Objective}

The general objective of the study is to find the extent to which transgender people are being empowered and enjoying their state of empowerment as a recognized citizen of Bangladesh.

\section{Specific Objectives}

To fulfill the general objective of the study there are some specific objectives that given bellow:

i. To determine the extent of transgender empowerment in Bangladesh respect to Social aspects.

ii. To determine the extent of transgender empowerment in Bangladesh respect to Political-Legal aspects.

iii. To determine the extent of transgender empowerment in Bangladesh respect to Economic aspects.

\section{Literature Review:}

The study reviews several theories related to the variables as well as empirical evidence from the different research papers and publications captured herewith. a. Theoretical Review: This section mainly focused on theories that anchor the study in terms of variables.

Transgender - In our day to day life we face various persons. Some of them seem to us surprising looking. They are neither women nor men in nature but they are the human being. In society they are popularly known as Transgender and in Indian subcontinent they are so called 'Hijra' people. Transgender people have a gender identity or gender expression that differs from their assigned sex (Altilio \& Otis-Green, 2011). Transgender- often shortened as trans- is also an umbrella term that includes people whose gender identity is the opposite of their assigned sex (trans men and trans women), it also includes people who are not exclusively feminine or masculine (people among whom are non-binary or gender-queer, including bigender, pangender, gender-fluid, or agender) (Forsyth \& Copes, 2014).

Transgender in Bangladesh - In Bangladesh, the cultural status of Hijras is now recognized as a specialist category 'third gender' on Bangladeshi national voters list by the government officials. Previously, the hijra community allowed applying their voting rights by signing up as men or women -as a result many were not interested and avoided doing so because they did not feel adequately represented. With the passes of time now transgender people can register to vote using their own identity as a hijra (Wallen, 2019). As per the government estimates there are around 10,000 hijras in Bangladesh although the other organizations those are working with hijras like- Bandhan Hijra Singha, a transgender rights group etc. saying their number could be around 100,000 .

Empowerment - Empowerment is a term refers to measures the degree of autonomy and selfdetermination in human being and in groups or communities in order to enable them to represent their interests and likings in a responsible and selfadministered way, by doing things on their own authority. So it is just the way of becoming stronger and more confident, especially to control one's life and to claim one's rights. Empowerment is basically as an action refers to both the process of self-empowerment and to professional assists of people, which enables 
them to overcome their sense of discouragements, powerlessness and lack of confidence, and to address and use their resources (Wikipedia, 2019).

Social Empowerment - Social empowerment is a broad area of practicing upon social work and community development principles. Generally Social Empowerment is implemented at the four following levels: (1) the individual level - where the person values himself/herself and wants to participate in life actively, (2) family level- where the person wants to be active in family life, (3) community level- where the person wants to be active in beyond their family life, and (4) social policies level- through local and national level actions to promote the social equities and inclusions of all level persons. Social level empowerment is vitally important to achieve its quality of life for people with disabilities and it is both a continuous process as well as a result. Though social empowerment can be achieved by other areas of practices like- inclusive education and socio-economic integration, it is also a specific area of practices where tools, methods and approaches exist to facilitate the social inclusion (Source, 2015).

Political/Legal Empowerment - Legal empowerment occurs when the poor or marginalized people use the law, legal systems and dispute resolution or redress mechanisms (formal and informal) to improve or transform their social, political or economical situations, to keep power holders to account or to beat unjust power relations. Legal empowerment can be individual or collective as a whole. The justice and legal mechanisms can be used as formal and provided by the government or state. In plural legal systems, the justice and redress is often served by the non-state actors and may not be recognized by law (informal). Different types of engagement with the law can be empowering. We focus on cases where the vulnerable or marginal people assert their interests or rights in the form of a claim or grievance through judicial and quasi-judicial mechanisms of dispute resolution, judicial reviews and legal accountabilities. Such initiatives or mechanisms ranges from the local community level, including the work of paralegals or engagement with non-state forms of dispute resolution and remedies, to strategic litigations in high courts or international and global forums. Legal empowerment can also be occurred through a wide array of social and horizontal accountabilities and mechanisms, such as administrative redress techniques, ombudsman and human rights commissions (Domingo and O'Neil, 2014).

Economic Empowerment - "Economic empowerment" can be explained as the development of the ability of the previously disadvantaged group of people to involve in economic and financial activities that benefit both the individuals in questions and the broader society. It is considered as a more productive and cost effective way to help those who would otherwise remain dependent on the social welfare system.

Welfare has its critics who argue that welfare removes the incentive to find employment while taking very much from the treasury. By empowering individuals to become financially or economically self-sufficient, they are erased from welfare payrolls and become more productive members of the society (Fischer, 2017). Economic empowerment in the country or state increases the access to economic resources and opportunities including jobs, property and other productive assets, financial services, skills development and market information regardless their gender identity (OECD, 2011).

Empowerment of Transgender People - Empowerment is the process or way of obtaining very basic rights and opportunities for marginalized or disadvantaged group of people, either directly by those people, or through the help of non-marginalized others who share their own access to these rights and opportunities. It also includes actively undertaken attempts to deny the rights and opportunities. Empowerment also includes motivating, influencing and developing the skills for self-efficiency.

This process may be hard to start and to implement in effective manner (Wikipedia, 2019). So, empowerment of transgender people can be defined as the way of achieving and receiving various social, political or legal and other economic benefits and opportunities from the state or by own accord for their growth and development Fig 1. 


\section{b. Empirical Review:}

This section highlights key readings relevant to the study. In Bangladesh Transgender community has been a part of our social system for a long time. Still their livelihoods are prorated into two major livelihoods. One is the conventional system collecting money from the general people, shops and markets. Another is opened for limited scope of marginal jobs. There are a very small number of transgender people are established. The fact behind this situation is not unknown to all. There is a socially accepted or constructed idea that these transgender or hijra people are only capable of doing some works to earn their day to day maintaining likesinging, dancing and collecting money. Even though they are capable of doing something else better than these sorts of activities, but most of the time they are ignored to achieve the opportunity (Orthy, 2018).

The transgender are entitled with constitutional fundamental rights and also the government recognized them in 2013 but still there are debates as to the enforcement of their basic rights for which they are neglected in every aspect of life starting from their primary education to professional fields, trade and business areas on the grounds that they are sexual minority people which introduced as neither man nor women. Because only recognition cannot change the traditional view of the society unless there is some special laws and social awareness (Pinkey, 2015). Hijra, the iconic figure of South Asian sexual and gender variances, comprise a publicly institutionalized subculture of male-bodied feminine-identified entity. Although they exist as a culturally recognized third gender for a long time, but recently they have got their legal recognition as third gender or hijras in several South Asian countries (Hossain, 2017). Globally, methamphetamine use is widespread among males who have sex with males (MSM) and transgender women (hijra), with studies indicating its alliance with risky sexual behaviors leading to HIV transmission (Khan et al., 2018).

Now, Economic empowerment of women and poverty alleviation has been of great concern to global economies most especially in African least developed countries. Most of the world's poor people are women and poverty cannot be eliminated or reduced if women

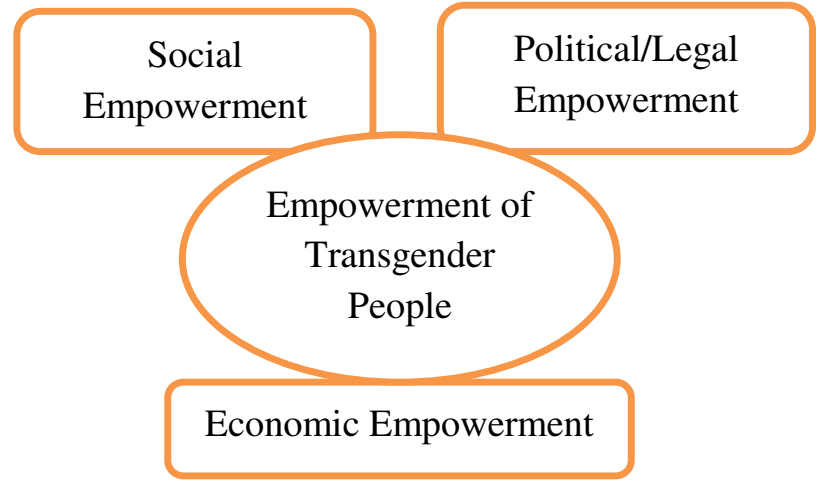

Fig 1: Empowerment of Transgender People.

are not economically empowered. Studies found that women control a very minute proportion of economic resources of countries of the world and in order to fit into and be able to operate within the mainstream of decision making, any group or sub-group must control a proportionate amount of productive resources (Danjuma et al., 2013).

Transgender (or Trans) men have a male gender identity that does not conform to the female sex declared at birth. There is a dearth of information on the experience of such men in Bangladesh. Many of the Trans men Human Rights Watch initially reached out to choose not to be interviewed because of security concerns, and those we did interview requested anonymity. Accordingly, we have used pen name and withheld information about their exact locations and ages of the interviews. There are four among the interviews with transgender men were conducted in person and two were over the phone (HRW, 2018).

Community empowerment is not just limited by the involvement, participation or engagement of communities rather it indicates something more like- it implies community ownership and action that precisely aims at social and political changes. Community empowerment is a way of re-allocating power in order to gain more control over the communities. It acknowledges that if some people are going to be empowered, then others will be able to share their existing power and capacity and giving some of it up (Baum, 2008). The amusement of the highest feasible standard of health is one of the basic rights of every human being. 
The right to health is consecrated in the International Convention on Economic, Social and Cultural Rights (ICESCR), to which Bangladesh conceded in 1998. This right has been translated as "a comprehensive right, granting not only to rapid and seemly health care, but also to the underlying components of health, such as access to safe and potable water and adequate sanitation, healthy occupational and environmental states, and entrance to health-related issues likeeducation and information, along with sexual and reproductive health knowledge" (Imtiaz, 2013).

\section{METHODOLOGY:}

A questionnaire survey based on Empowerment of Transgender People in Bangladesh was conducted in the National Memorial based area Savar, Dhaka to collect data. The survey method is appropriate for this kind of study as it provides quantitative description of attitudes, experience and opinions of the sample population (Creswell, 2003).

This study has applied descriptive research design with quantitative approach to determine the extent of each factor in influencing the empowerment of transgender people in Bangladesh. The target population was 60-80 transgender people live in Savar National Memorial based area in Dhaka city. Purposive sampling technique was used to set the sample size. To formulate an adequate sample size $10 \%-30 \%$ of the target population is expected (Mugenda and Mugenda, 2003).

The sample size of the study was 28 respondents from the population. To collect primary data the closeended structured questionnaire was given to the selected respondents of the transgender community.
The instruments were of five point Likert scale format to ensure that the respondents are guided well in answering the questions.

The instruments of the questionnaire were divided into five sections. Section A contained the questions regarding respondent's general information, Section B contained the respondent's perception about their overall empowerment, Section C contained the questions regarding Social Empowerment of Transgender People, Section D contained the questions regarding Political/Legal Empowerment of Transgender People and section $\mathrm{E}$ focused on the questions of Economic Empowerment of Transgender People.

Data was analyzed by using descriptive analysis (means and standard deviation), correlation analysis (Pearson correlation) and multiple regression analysis. The regression model is given below:

$$
Y=\beta_{0}+\beta_{1} X_{1}+\beta_{2} X_{2}+\beta_{3} X_{3}+e
$$

Where:

$\mathrm{Y}=$ Empowerment State of Transgender People.

$\beta_{0}=$ Constant

$\beta_{1}-\beta_{3}=$ Beta coefficients.

$\mathrm{X}_{1}=$ Social Empowerment of Transgender People (SocEm).

$\mathrm{X}_{2}=$ Political-Legal Empowerment of Transgender People (PoLeEm).

$\mathrm{X}_{3}=$ Economic Empowerment of Transgender People (EcoEm).

$\mathrm{e}=$ Error Term .

\section{Descriptive Analysis}

Table 1: Descriptive Statistics of the Transgender People.

\begin{tabular}{lrrr} 
& Mean & Std. Deviation & N \\
Perception of the respondents about their overall empowerment & 3.11 & 0.832 & 28 \\
\hline Social Empowerment of Transgender People (SocEm) & 2.9439 & 0.56923 & 28 \\
Political/Legal Empowerment of Transgender People (PoLeEm) & 2.8973 & 0.55073 & 28 \\
Economic Empowerment of Transgender People (EcoEm) & 3.4206 & 0.69049 & 28
\end{tabular}




\section{ANALYSIS AND FINDINGS:}

Data was analyzed through descriptive analysis (means and standard deviation) and multiple regression analysis, to test the significance of extent to which transgender people are being empowered and enjoying their empowerment as a recognized citizen of Bangladesh.

$>$ Transgender respondents strongly agreed at 2.9439 that the Extent of Social empowerment has the influence on their Perception of overall empowerment.

$>$ The selected Transgender respondents agreed at 2.8973 that Political/Legal Empowerment has the influencing power on their overall empowerment.

$>$ Most of the selected Transgender respondents strongly agreed at 3.4206 that the Effects of Economic Empowerment has the impact on their Perception of overall empowerment.

\section{Multiple Regression Analysis}

This section presents a discussion of the results of inferential statistics. The researchers introduced a multiple regression analysis to determine the extent of each of the variables of the empowerment of transgender respect to selected transgender people those who live in Savar National Memorial based area in Dhaka City.

The researcher used the statistical package SPSS-23 to enter and compute the measurements of the multiple regressions for the study and the P-values are incorporated in reference to significance level of 0.05 . Findings are presented in the following tables;

Table 2: Model Summary of the Transgender People.

\begin{tabular}{|c|c|c|c|c|c|c|c|c|c|}
\hline \multirow[t]{2}{*}{ Model } & \multirow[t]{2}{*}{$\mathbf{R}$} & \multirow[t]{2}{*}{ R Square } & \multirow{2}{*}{$\begin{array}{l}\text { Adjusted } \\
\text { R Square }\end{array}$} & \multirow{2}{*}{$\begin{array}{l}\text { Std. Error } \\
\text { of the } \\
\text { Estimate }\end{array}$} & \multicolumn{5}{|c|}{ Change Statistics } \\
\hline & & & & & $\begin{array}{c}\text { R Square } \\
\text { Change }\end{array}$ & $\begin{array}{c}\mathrm{F} \\
\text { Change }\end{array}$ & df1 & $\mathrm{df} 2$ & $\begin{array}{l}\text { Sig. F } \\
\text { Change }\end{array}$ \\
\hline 1 & $0.955^{\mathrm{a}}$ & 0.912 & 0.901 & 0.261 & 0.912 & 83.288 & 3 & 24 & 0.000 \\
\hline
\end{tabular}

a. Predictors: (Constant), Economic Empowerment of Transgender People (EcoEm), Political/Legal

Empowerment of Transgender People (PoLeEm), Social Empowerment of Transgender People (SocEm)

Table 3: ANOVA ${ }^{\mathrm{a}}$ Table of the Empowerment of Transgender People.

\begin{tabular}{|c|c|c|c|c|c|c|}
\hline \multicolumn{2}{|c|}{ Model } & Sum of Squares & df & Mean Square & $\mathrm{F}$ & Sig. \\
\hline \multirow[t]{3}{*}{1} & Regression & 17.042 & 3 & 5.681 & 83.288 & $0.000^{\mathrm{b}}$ \\
\hline & Residual & 1.637 & 24 & \multirow[t]{2}{*}{0.068} & & \\
\hline & Total & 18.679 & 27 & & & \\
\hline
\end{tabular}

a. Dependent Variable: Perception of the respondents about their overall empowerment.

b. Predictors: (Constant), Economic Empowerment of Transgender People (EcoEm), Political/Legal

Empowerment of Transgender People (PoLeEm), Social Empowerment of Transgender People (SocEm).

From the above Table 2, Coefficient of determination explains the extent to which changes in the dependent variable can be explained by the changes in the independent variables or the percentage of variation in the dependent variable (Perception of the respondents about their overall empowerment) that is explained by all the three independent variables (Economic Empowerment of Transgender People (EcoEm).
Political/Legal Empowerment of Transgender People (PoLeEm), Social Empowerment of Transgender People (SocEm). The three independent variables that were studied, explain $91.20 \%$ of variance in Perception of the respondents about their overall empowerment (Empowerment of Transgender people) respect to selected transgender people those who live in Savar National Memorial based area in Dhaka City 
as represented by the $\mathrm{R}^{2}$. Therefore this means that other factors not studied in this research contribute $8.80 \%$ of variance in the dependent variable. Therefore further research should be conducted to find the extent of transgender empowerment regarding social, political-legal and economic aspects in Bangladesh.

From the above Table 3: ANOVA Table, results indicate the overall goodness of fit in terms of the extent of transgender empowerment respect to collective impacts of social, political-legal and economic aspects of selected transgender people those who live in Savar National Memorial based area in Dhaka city. The $\mathrm{P}$ value is 0.000 , which is less than the significant level of 0.05 . Hence, the model is overall a good fit. Consequently social, political-legal and economic aspects of selected transgender people is a good measure of their empowerment state in Bangladesh those who were studied.

Table 4: Coefficients ${ }^{\mathrm{a}}$ Table of the Transgender People.

\begin{tabular}{|c|c|c|c|c|c|c|}
\hline \multirow{2}{*}{\multicolumn{2}{|c|}{ Model }} & \multicolumn{2}{|c|}{$\begin{array}{l}\text { Unstandardized } \\
\text { Coefficients }\end{array}$} & \multirow{2}{*}{$\begin{array}{c}\text { Standardized } \\
\text { Coefficients } \\
\text { Beta }\end{array}$} & \multirow[t]{2}{*}{$\mathbf{t}$} & \multirow[t]{2}{*}{ Sig. } \\
\hline & & B & Std. Error & & & \\
\hline \multirow[t]{4}{*}{1} & (Constant) & -0.954 & 0.276 & & -3.453 & 0.002 \\
\hline & $\begin{array}{l}\text { Social Empowerment of Transgender } \\
\text { People (SocEm) }\end{array}$ & 0.590 & 0.240 & 0.404 & 2.458 & 0.022 \\
\hline & $\begin{array}{l}\text { Political/Legal Empowerment of } \\
\text { Transgender People (PoLeEm) }\end{array}$ & -0.050 & 0.210 & -0.033 & -0.240 & 0.812 \\
\hline & $\begin{array}{l}\text { Economic Empowerment of } \\
\text { Transgender People (EcoEm) }\end{array}$ & 0.722 & 0.219 & 0.599 & 3.299 & 0.003 \\
\hline
\end{tabular}

a. Dependent Variable: Perception of the respondents about their overall empowerment

Significant Level $=0.05$

From the above Table 4: Coefficients Table, the following regression function is extracted;

$$
Y=-0.954+0.590 X_{1}-0.050 X_{2}+0.722 X_{3}
$$

Where: $Y=$ Perception of the respondents about their overall empowerment (Empowerment of Transgender People), $\beta_{0}=$ Constant, $X_{1}=$ Social Empowerment of Transgender People (SocEm), $\mathrm{X}_{2}=$ Political/Legal Empowerment of Transgender People (PoLeEm), $\mathrm{X}_{3}=$ Economic Empowerment of Transgender People (EcoEm). The beta coefficients indicate the change in Overall empowerment of transgender people attributed to a unit change in the predictor variables if all other factors held constant. Hence, a unit change in Social Empowerment of Transgender People (SocEm) causes a 0.590 change in Overall Empowerment state of Transgender people in Savar National Memorial based area in Dhaka city, while all other factors held constant. A unit change in Political/Legal Empowerment of Transgender People (PoLeEm) causes a -0.050 change in Overall Empowerment state of Transgender people in Savar National Memorial based area in Dhaka city, while all other factors held constant.

A unit change in Economic Empowerment of Transgender People (EcoEm) causes a 0.722 change in Overall Empowerment state of Transgender people in Savar National Memorial based area in Dhaka city, while all other factors held constant. The above scenario indicates that all the independent variables except Political/Legal Empowerment of Transgender People (PoLeEm) have the significant influence on Perception of the respondents about their overall state of empowerment (Empowerment of Transgender People) respect to selected transgender people those who live in Savar National Memorial based area in Dhaka city. 


\section{CONCLUSION:}

Transgender people are one of the marginalized groups of people in all over the world and in Bangladesh there is no exception. They are economically concerned. Inevitable factors and components are preventing them from further economic development. In the context of Bangladesh, social systems are at the root points of the structural violence. Social environments, norms, and stigma are pushing the transgender community to the marginal edge every day. Inequality in power relationships and sociopolitical culture are becoming hindrance to identifying themselves as who they are (Orthy, 2018). The problem will be solved only when the transgender people of the country will sufficiently be empowered in all aspects like- socially, economically and legally/ politically. With the passes of time the scenario is being changed and now the transgender people are being accepted in all phases of the society, state and country. Presently there are many examples are available that represents their acceptance in the country by the general people. They are now getting some privileges day by day and getting involved in several socio-economical activities. By this they are being empowered bit by bit. This study was an attempt to find the limit to which changes in the dependent variable can be illustrated by the changes in the independent variables or the percentage of variation in the dependent variable (Perception of the respondents about their overall empowerment) that is illustrated by all the three independent variables Economic Empowerment of Transgender People (EcoEm), Political/ Legal Empowerment of Transgender People (PoLeEm), Social Empowerment of Transgender People (SocEm)). As evident from this study, transgender people are now being empowered especially in economic and social perspective but there is a limited way. Since they are the part of our society and we can't ignore their existence and that is why they need to give more emphasis on their empowerment to sustain the continuous growth and development of the country.

\section{ACKNOWLEDGEMENT:}

Many thanks, to the co-workers supporting for successful completion of the research work.

\section{CONFLICTS OF INTEREST}

The authors declared no potential conflicts of the interest with respect to the research, authorship and/or publication of this article.

\section{REFERENCES:}

1. Ahmed, S. (2017). Recognition of 'Hijra' as Third Gender in Bangladesh. Bringing changes. Improving lives. Keeping promises. www.bandhu-bd.org

2. Altilio, T. \& Otis-Green, S. (2011). Oxford Textbook of Palliative Social Work. Oxford University Press. p. 380. ISBN 978-0199838271.

3. Baum, F. (2008) Foreword to Health promotion in action: from local to global empowerment. WHO Commission on Social Determinants of Health.

4. Creswell, J. W. (2003). Research Design: Qualitative, Quantitative, and Mixed method Appro-aches, $2^{\text {nd }}$ ed. Sage Publication, Thousand Oaks, California.

5. Danjuma, S. K., Muhammad, Y. A. \& Alkali, L. F. (2013). Factors Militating Against Women Economic Empowerment and Poverty Reduction in African Countries. IOSR Journal of Business and Management. 13(6), 47-51.

6. Delliswararao, K. and Hangsing, C. (2018). "Socio-Cultural Exclusion and Inclusion of Trans-genders in India" (2018). Int. J. Soc. Sc. Manage. 5 (1): 10-17. https://doi.org/10.3126/ijssm.v5i1. 18147

7. Domingo, P. and O'Neil, T. (2014). The politics of legal empowerment: Legal mobilization strategies and implications for development. Shaping policy for development, odi.org. ISSN: 2052-7209.

https://www.odi.org/sites/odi.org.uk/files/odi-assets/publications-opinion-files/ 9008.pdf

8. Fischer, W. (2017). "What's the definition of Economic Empowerment?" eNotes Editorial, 14 Sep. 2017,

https://www.enotes.com/homework-help/whatsdefinition-economic-empowerment-454154

9. Forsyth, C.J. \& Copes, H. (2014). Encyclopedia of Social Deviance. Sage Publications. p. 740. ISBN 978-1483364698. 
10. Hossain, A. (2017). The paradox of recognition: hijra, third gender and sexual rights in Bangladesh, Culture, Health \& Sexuality, 19:12, 1418-1431. https://doi.org/10.1080/13691058.2017.1317-831

11. Human Rights Watch. (2018). Bangladesh: Transgender Men Fear for Their Safety. Transgender Men Face Threats and Widespread Discrimination. Human Rights watch, Bangladesh Perspective, January 19, 2018.

12. Imtiaz, D. S. S. (2013). Report to the Regional national human Rights institutions project on inclusion, the Right to health and sexual orientation and gender identity. National Human Rights Commission of Bangladesh.

13. Khan, S.I., Khan, M.N.M., Hasan, A.M.R., Irfan, S.D., Horng, L.M.S., Chowdhury, E.I. \& Azim, T. (2018). Understanding the reasons for using methamphetamine by sexual minority people in Dhaka, Bangladesh. International Journal of Drug Policy, 73, 64-71.

14. Mugenda, M. O. \& Mugenda, G. A. (2003). Research Methods. Nairobi: Acts Press.

15. NHRC. (2015). "Third Gender is not a Word, it is a Gender", Organized by Bandhubs and National Human Rights Commission, [June 7, 2015]

http://www.bandhu-bd.org/third-gender-is-not-aword-it-is-a-gender/

16. OECD. (2011). Women's economic empowerment. OECD, Better policy for better lives. https://www.oecd.org/dac/gender-devel-opment/ womenseconomicempowerment.htm

17. Orthy, S. R. K. (2018). Transgender Community in Bangladesh: A study on resistance to structural violence for a better livelihood. https://www.academia.edu/39366-946/Transg-end er_Community_in_Bangladesh_A_study_on_resis tance_to_structural_violence_for_a_better_livelih ood

18. Pinkey, R. R. (2015). Recognition of Transgender as Third Gender: an Analysis of Their Education and Employment Right. Dissertation Paper, Department of Law, East West University, Dhaka, Bangladesh.

19. Sema SA. (2019). The Subversive Use of Parading Effeminacy by Transgender People in increasing Crime Rate in Bangladesh: A Study on Several Investigating Crime Reports, $B r . J$. Arts Humanit., 1(6), 45-55.

https://doi.org/10.3 4104/bjah.019.45055

20. Source. (2015). Social empowerment. International online resource Centre on disability and inclusion.

https://asksource.info/topics/social-inclusion/soci al-empowerment

21. UN. (2016). Sustainable Development Goals, Knowledge Platform. United Nations.

https://sustainabledevelopment.un.org/?menu=130 $\underline{0}$

22. Wallen, J. (2019). Transgender community in Bangladesh finally granted full voting rights. The Telegraph.

https://www.telegraph.co.uk/global-health/climateand-people/transgender-community-bangladeshfinally-granted-full-voting/

23. Wikipedia. (2019). Empowerment. https://en.wikipedia.org/wiki/Empowerment

Citation: Sema SA, and Islam MT. (2020). Empowerment state of transgender people in Bangladesh: a study on Savar national memorial based area in Dhaka city, Asian J. Soc. Sci. Leg. Stud., 2(1), 1-10. https://doi.org/10.34104/ajssls.020.01010 C) () 